\title{
Financialization revisited: the rise and fall of finance-led capitalism *
}

\author{
Robert Guttmann **
}

\begin{abstract}
Financialization, expressing the growing importance of finance in the modus operandi of our capitalist system, has emerged as a key concept in various heterodox approaches over the last dozen years - be they Post-Keynesians (E. Stockhammer, E. Hein), American Radicals (G. Epstein, G. Krippner), Marxists (J. Bellamy Foster, G. Dumenil) or French Régulationists (M. Aglietta, R. Boyer). But until now those various analysts have each looked at this very complex phenomenon from one or the other specific angle. In this article, I am trying to provide a more comprehensive analysis of financialization by tracing its two primary drivers - structural changes making non-financial actors more dependent on debt-financing as well as financial-income sources ("financial centralization") while also giving increased weight to the financial sector in the economy ("financial concentration"). The complex interaction between financial centralization and financial concentration has yielded a financialized growth dynamic fueling consecutive debt-financed asset bubbles in the center, the United States, that spurs export-led growth in the periphery. Framing this financialized growth dynamic in the Régulationist context as a historically conditioned accumulation regime, finance-led capitalism, I analyze its rise $(1982$ - 2007) in the wake of key changes in finance and its subsequent structural crisis (2007-2012) to provide a more complete approach to the crucial phenomenon of financialization.
\end{abstract}

Keywords: Financialization; Finance-led capitalism; Securitization; Shadow banking; US dollar as world money.

\section{Resumo}

\section{Financeirização revisada: a ascensão e queda do capitalismo liderado pelas finanças}

A financeirização, expressão da crescente importância das finanças no modus operandi do sistema capitalista, surgiu como um conceito-chave em várias abordagens heterodoxas nos últimos doze anos dos pós-keynesianos (E. Stockhammer, E. Hein), radicais americanos (G. Epstein, G. Krippner), marxistas (J. Bellamy Foster, G. Dumenil) e regulacionistas franceses (M. Aglietta, R. Boyer). Até hoje, esses analistas se debruçaram sobre esse fenômeno complexo a partir de diferentes ângulos. Neste artigo, procura-se fornecer uma análise mais ampla da financeirização traçando seus dois principais determinantes: por um lado, mudanças estruturais que tornaram os agentes não-financeiros mais dependentes de financiamento mediante dívidas, assim como de fontes de ingressos financeiros ("centralização financeira"); por outro lado, o aumento do peso do sistema financeiro na economia ("concentração financeira"). A complexa interação entre a centralização e a concentração financeiras resultou numa dinâmica de crescimento financeirizado, alimentando consecutivas bolhas de ativos financiadas por dívida no centro, os Estados Unidos, e estimulando o crescimento liderado pelas exportações na periferia. A partir da análise desta dinâmica de crescimento financeirizado numa perspectiva regulacionista - ou seja, como um determinado regime de acumulação, o capitalismo

* Article received on March 23, 2017 and approved on September 18, 2017.

** Chair in Economics, Hofstra University, New York / Associate Professor, CEPN, Paris. E-mail: robert.p.guttmann@hofstra.edu. 
conduzido pelas finanças - este artigo analisa sua ascensão (1982 - 2007) na esteira de mudanças-chave nas finanças e sua subsequente crise estrutural (2007-2012) para fornecer uma abordagem mais completa para o fenômeno crucial da financeirização.

Palavras-chave: Financeirização; Capitalismo liderado pelas finanças; Securitização; Sistema bancário sombra; Dólar americano como moeda mundial.

JEL G32.

Amidst overwhelming evidence that our capitalist system has become increasingly shaped by financial institutions and markets, heterodox economists of different stripes (e.g. Post-Keynesians, American Radicals, French Régulationists) have in recent years made increasing reference to the term "financialization" to analyze the modus operandi of contemporary capitalism. This concept has thus emerged as a crucial notion among those economists seeking an alternative vision to the mainstream neo-classical world of a-historic "equilibrium economics." In revisiting this concept, I want to embed "financialization" more broadly at the center of a historically conditioned phase in the evolution of our capitalist system, namely that of finance-led capitalism whose rise engulfed the entire world economy in the 1990s and early 2000s only to explode into the most severe global crisis since the Great Depression eighty years ago - the Great Recession of 2007/08. Secularstagnation conditions and a highly constraining re-regulation of finance since then have begun to push capitalism away from its excessive reliance on the highly aggressive expansion of finance, perhaps in the direction of "ecological capitalism" readying itself for the great battle with climate change.

\section{The heterodox notion of financialization}

In the run-up to the crisis of 2007/08 the dominant position of financial institutions and markets had become so unmistakable that it prompted several heterodox economists to push their critical analyses of capitalism a bit further by invoking the notion of its growing financialization. In 2005 the American Radical economist Gerald Epstein provided a definition of that phenomenon which soon became consensually accepted as the one used most widely: financialization "means the increasing role of financial motives, financial markets, financial actors and financial institutions in the operation of the domestic and international economies." That same year the famous US sociologist Greta Krippner gave the notion a statistical-measurement dimension in order to shed more light on who controls the leading US corporations today and how their intertwining with global finance has come to undermine the economic-policy space of nominally sovereign nation-states. She followed up this introduction several years later with a study of financial deregulation amidst dramatic changes in monetary and fiscal policy under the Reagan Revolution to trace the historic origins of financialization to America's resolution of the stagflation crisis from October 1979 onward. Just at the onset of the 
crisis leading European Post-Keynesian economists Eckhard Hein and Engelbert Stockhammer embedded financialization in growth and distribution models. They both pointed out how the financial explosion of recent years has made income distribution more unequal while also feeding industrial stagnation by diverting so many resources from productive investments to short-term speculation. Since then the term has made it into the mainstream, being adopted by such ruling-elite institutions as Forbes Magazine, New York Times, or Investopedia.com ${ }^{1}$.

But this elaboration of the notion of "financialization," starting with Epstein's rather broad definition of the phenomenon in 2005, has included a host of different manifestations of finance's growing importance, including a disproportionate increase of the financial-services sector, the explosion in the size and variety of financial markets, the dominance of financial motives, and the heavy accumulation of financial assets and liabilities among a wide range of actors. Subsequently, each specialist in the field has approached this arguably vast and complex topic with a particular facet. One may be concerned with the distributional impact benefiting holders of financial assets (see T. Palley, 2007), the other with the profit-rate differences between financial and non-financial firms (see J. Bellamy Foster, 2007), a third with the growing size of the finance sector, and so forth. Besides being overly narrow in its separate focus on specific aspects which are thus kept artificially apart from each other, this research is also of a comparative-static nature, looking at a pre-financialization ("before") norm for the particular aspect chosen, typically around 1973, and then comparing that with a more recent anchor level ("after") for the same variable. I would like to provide here instead a more comprehensive, integrative, and dynamic approach to the financialization process.

We start by figuring out how and why non-financial actors accumulate financial assets such as bonds or stocks. This kind of asset is inherently attractive because of its liquidity as well as its mobility. It also serves as an alternative source of income (interest, dividends, capital gains) and gives its owner greater command in the marketplace, a modicum of power. I would like to define this propensity in favor of financial assets by non-financial actors as a matter of financial centralization, a term that accurately implies the increasingly important presence of financial assets in the balance sheets of households or industrial enterprises. Those very same non-financial actors have also ended up with more financial liabilities (i.e. debt) on the other side of their balance-sheet ledger, as they learned gradually to live with higher levels of debt. This proportional increase in financial assets and liabilities on the balance sheets of non-financial actors coincided with the rapid growth of the institutions and markets providing finance, a trend we shall characterize as one of financial concentration. That expansion was fed by the simultaneous deregulation,

(1) See G. Epstein (2005, p. 1); G. Krippner (2005; 2012), E. Hein and T. Van Treeck (2008), as well as E. Stockhammer (2008). 
computerization, and globalization of finance. The rapid pace of financial innovation, which emerged in the wake of this triple transformation in the nature of finance, engendered new financial markets and networks, allowed more nodes connecting those to each other, and created new liquidity pumps feeding their volume. As it gained density and scale, that self-expanding web of financial markets and networks began to alter the growth pattern of our economy, a third aspect of financialization best characterized as the financial growth dynamic. Growth became more dependent on higher debt levels and became subject to recurrent asset bubbles while a steadily rising financial income share created a lot of re-distributional pressure on (stagnant) profit shares and (broadly declining) wage shares - a phenomenon witnessed in nearly all advanced capitalist nations during the quarter century preceding the crisis of 2007/8. As the asset bubbles collapsed one after another, falling asset prices clashed with an inelastic debt structure. That clash imposed crisis-induced adjustments as desperate debtors had to slash spending, sell off assets into declining markets, and get debt levels down - all this to avoid turning illiquidity into insolvency. Even before the Great Recession of 2007/8, the world faced many incidences of financial instability.

\section{Financial centralization}

Financial centralization denotes a process whereby non-financial actors, both firms as well as households, "financialize" inasmuch as they end up accumulating much larger stocks of financial assets and liabilities. Not only do they thereby derive a much larger share of their total income in the form of financial income (e.g. interest, dividends, capital gains), but they also expose themselves to higher (fixed-cost) debt servicing charges in the face of rising debt levels. These parallel changes in their income-payment structure naturally make these nonfinancial actors prone to accord financial motives much more space in their decisionmaking and prioritizing choices. In what follows we shall demonstrate that this aspect of "financialization" emerged in the wake of a broader transformation of the US economy as it emerged out of its stagflation crisis of the 1970s.

\subsection{Money-market funds}

The birth of financialization can be dated to 1975 in the United States with the introduction of money-market funds. These funds invest in highly liquid moneymarket instruments (e.g. Treasury bills, commercial paper) while offering their investors deposit-like shares that can be withdrawn on demand. Unlike traditional savings deposits which at that point had maximum ceilings on their interest rates imposed by the Fed, the money-market funds offered market yields that were higher than the Fed's ceilings. The funds counteracted the banks' deposit insurance advantage by promising to keep the net asset value of their shares under all 
circumstances at one dollar per share, guaranteeing that investors in those funds would get their principal back. The immediate popularity of the MMFs for the first time turned millions of American households in the late 1970s and early 1980s into investors owning portfolios, as those investor-based funds replaced bank deposits as America's primary form of savings ${ }^{2}$.

\subsection{Pension plans}

This new reality of making Americans own more financial assets was greatly reinforced when US firms switched pensions from defined-benefit plans to definedcontribution plans, following the introduction in 1980 of the very popular $401(k)$ plans - a tax-deferred defined-contribution plan where taxation of contributions and gains is postponed until employees retire and begin to draw benefits from their pension. Those tax advantages obscured the fact that with defined-contribution plans future benefit pay-outs were no longer pre-determined in advance by a corporate promise (as used to be case with the defined-benefit plans), but depended instead on accumulated portfolio returns so that the risk was thereby transferred from the employer to the workers. This change led an even larger (and younger) number of Americans becoming investors who were thus motivated to know about the inner workings of financial markets. Rather than getting upset at the transfer of risk, the majority of workers liked the fact that they had now gained direct personal control over their private pension plans when they were turned from defined-benefit plans into defined-contribution plans. It also helped that Americans, optimistic by nature, believed at that point in the superior long-term performance of the stock market so as not to worry too much about their future returns and pension benefits being adequate.

\subsection{Reagan's tax reform}

These fundamental changes in the structure of American household savings were further reinforced when the arch-conservative politician Ronald Reagan took over the White House in January 1981. Attacking income-maintenance programs as "hand-outs" and "socialistic," Reagan even pushed for privatization of Social Security. Even though his more radical proposals never passed through Congress, Reagan altered the discourse of American politics. He offered an alternative vision of an "ownership society", highlighting the virtues of personal responsibility and freedom of choice. This vision fell on eager ears among many Americans who had become disappointed with the frequent policy shifts of the Democrats trying in vain

(2) The banks responded to this competitive challenge from their less regulated MMMF rivals by pushing for deregulation of interest-rate ceilings on their deposits. This deregulation, however, took a decade to be achieved, and the banks never recovered their once-dominant position vis-à-vis household savings in the United States. For more on the major implications of this structural shift in US savings see M. Cipriani, A, Martin, and B. Parigi (2013). 
to fight rising unemployment while simultaneously accelerating inflation. Most importantly, Reagan introduced fiscal reforms that reinforced the emergence of a patrimonial middle class beginning to accumulate large amounts of securities through its mutual and pension funds. He lowered tax rates substantially across the board twice, in 1981 and in 1986, thereby slashing the top marginal tax rate from 70 percent to just 28 percent. Suddenly it made a lot of sense for top earners in particular to gain more income, as they were able to keep most of it for themselves rather than having much of it go to the government. Reagan strengthened this incentive even more when he cut the tax rate for capital gains to just 15 percent. His radical 1981 tax reform came at a moment when successful disinflation would cause a gradual, but steady decline of interest rates to take root and go on over many years to boost the bond and stock markets. This was perfect timing! Soon the US managerial class switched its principal form of pay from cash to lightly taxed stock options, a trend that has continued unabated to date. The result was a huge boost to the income share going to the top 10 percent comprising the managerial class in the United States ${ }^{3}$. Perhaps even more importantly, stock options reinforced another crucial pillar of financial centralization, namely the dictate of shareholder value maximization, which became the guiding principle of corporate governance in the 1980s.

\subsection{Shareholder value maximization}

US corporations had seen their share prices end up seriously undervalued in the wake of accelerating inflation causing systematic valuation errors (capitalizing real cash flows with nominal interest rates, failing to recognize capital gains from the lowering of nominally fixed liabilities by inflation). Once inflation had been wrung out of the system by mid-1982 (and with it distorting accounting profits), the US stock market started one of the strongest bull markets ever. Driving this boom was a group of aggressive "corporate raiders" attacking a wide array of US companies, especially those considered particularly undervalued, with hostile takeover bids which they financed by issuing high-yielding "junk" bonds that had been popularized in the early 1980s by investment bank Drexel. These raiders (Ivan Boesky, C Boone Pickens, Carl Icahn, etc.) used this new funding tool to maximum effect to earn huge gains. Many companies they attacked either had to pay off the raiders handsomely to stop their attack or be taken over only to be dismantled and have their pieces sold off separately. When the corporations chose to defend themselves against these raids, they had to convince mutual funds and/or pension funds owning large chunks of their shares to side with them and not sell out to the raiders. To the extent that these institutional investors sided with management, they did so under the condition that the firm restructure in order to significantly raise share

(3) The Compustat Execu Comp database shows the top-manager ("CEO”)-to-worker compensation ratio, including options exercised, to have risen in the US from 29 in 1978 to a peak of 343.4 in 1999 and a still considerable 231 in 2010 . 
prices. This same process would play itself out among the initial target's major competitors, once the raiders' moves began to be followed by a growing number of investors caught in the grip of this emerging stock-market bubble. When the raiders attacked one particular firm in any given industry, other firms in that sector also had to restructure as they became takeover targets. It is in the context of this bubbledriven restructuring frenzy from 1982 to 1987 that shareholder value maximization became the new mantra. The emerging practice of paying corporate managers in stock options was meant to reassure shareholders that the priorities of managers were being aligned with their own interests.

Since then, it has become obvious that this principle of corporate governance, besides crowding out other stakeholder interests (e.g. consumers, workers, local communities), has made short-term bottom-line considerations the sole corporate criterion of success at the expense of long-term investment horizons. Firms spend more and more on financial manipulations (e.g. share buybacks, stock splits) and less and less on productive investments. Shareholder value maximization helped generate a widespread obsession with quarterly earnings. Longer-term objectives, such as skill formation or research and development, get neglected even though they may be crucial for the long-term profitability of the firm. Pressed by impatient shareholders, managers are also more inclined to favor reflexive costcutting responses, accumulation of cash cushions, and reliance on external-growth strategies acquiring existing capacities through mergers and takeovers rather than building new capacity from scratch. Shareholder-dominated firms may also take on a lot of debt to boost rates of return to shareholders ${ }^{4}$.

\subsection{The firm as an asset bundle}

Following the collapse of Bretton Woods in 1971, in 1974 the US began to dismantle its capital and exchange controls, a process that was extended during the 1980 s to the rest of the world. Increasingly integrated capital markets combined with the worldwide liberalization of capital flows in the early 1990s triggered a global boost in cross-border capital flows. The world flows of foreign direct investment grew at an average of 13 percent per year between 1990 and 1997 and then surged to annual growth rates of 50 percent during 1998-2000. Following the FDI contraction during the 2000/01 recession, the pace of FDI sped up from 2003 on to triple the global volume by 2007 when it peaked at just over $\$ 2$ trillion ${ }^{5}$. Multinational enterprises understood that they had an once-in-a-lifetime chance to

(4) The use of high debt levels to boost returns is known as the leverage effect. Debt allows the capital base of a firm to stay small relative to its asset size so that any given level of profits translates into a higher rate of return (due to the proportionately smaller denominator, i.e. capital in the form of shareholders' equity).

(5) See International Monetary Fund (2003) and Unctad (2013). Since the crisis, the FDI volume has fluctuated between $\$ 1.3$ trillion and $\$ 1.6$ trillion. 
capture new markets. Huge advances in communication and information technologies, coupled with sudden access to hundreds of millions of eager low-wage workers, pushed those MNEs much further along their globalization path - the transformation of multinational companies into global production networks, comprising many subsidiaries and affiliates to produce bits and pieces of increasingly standardized and globally marketed products and so forming integrated global supply chains. From the perspective of their home countries, these once celebrated national champions now came to be regarded as less than patriotic as they shrank domestic production facilities in favor of outsourcing and off-shoring - a development that has soured many workers in the industrial nations on the idea of globalization.

But the more these global production networks decentralized production and spread it out geographically, the more they needed to centralize control over cash flows in order to manage their far-flung networks. Their administrative center, often organized as a holding company, is today not least a giant cash-collection and reallocation apparatus. That center deals with its global network of suppliers through a variety of relationship-reinforcing arrangements such as cross-shareholdings, lines of credit, trade credit, licensing agreements, joint ventures, and long-term supply contracts. Once local stock markets emerged successfully in key emerging markets over the last two decades - from Sao Paulo to Shanghai - many emerging-market firms could become global players themselves while at the same time making it easier for American, European, or Japanese firms to build and adjust their networks. The stock market is a very powerful mechanism for strategic re-adjustments and sectoral re-groupings, making an important contribution to the accelerating change in industry structures towards global oligopoly. In more and more manufacturing, high-tech, and even service industries there will eventually only be a few of these GPNs left, obliging firms lacking adequate scale for a leadership position to choose new partners and divest from marginal activities in order to focus on their core competencies.

The global market leaders today are in that sense better understood as holding companies managing bundles of productive and financial assets at their disposal, who shuffle around their strategic holdings. As such they are not necessarily wedded any longer to a particular product even when that product is what put the firm originally on the map. Shareholder value maximization, with its relentless emphasis on current earnings, makes firms less vested in patiently building a long-term market position in a specific industry and instead shifting the focus of attention to accumulation of cash, a high rate of self-financing, financial manipulations to increase share prices (e.g. stock buy-backs, stock splits), divestitures and spin-offs, and finally external growth by means of takeovers, 
mergers, and acquisitions rather than building capacity from scratch. This phenomenon is known as "hollowing out."

\section{Financial concentration}

In conjunction with financial centralization leaving non-financial actors with substantially more financial liabilities ("debt") and financial assets, there has also been a phenomenal expansion of finance over the last three decades. Both banks and non-bank financial institutions have ended up absorbing significantly larger shares of a nation's gross domestic product, employment, or total corporate profit. Finance is thus today a much larger sector in the economy of the advanced capitalist nations. But it is actually more than a sector. We need to understand it more accurately as a system around which the economy organizes itself. This view of finance as a system calls for a meso-economic level of analysis through which we can see how finance as a system connects the micro-level of individual actors functioning as debtors and investors to the macro-level of a nation's savings, business investment, consumption, government spending, and foreign trade balance. This systemic, meso-economic view of finance focuses in particular on how, over the years, it has become so much more capable of rapid self-expansion. That extraordinary pace of growth, implying a much more active, dynamic, and strategic role in funding the economy came about amidst deep and profound structural changes in how finance operates.

\subsection{Funds replace bank deposits as primary source of savings}

A major financial innovation in the early 1960s, the so-called Eurocurrency markets, saw banks create a worldwide network that operates supra-nationally in a stateless space beyond the reach of any national regulator. The globalization of finance was born right there, and immediately overpowered the capital controls in place, including those set up by the greatest power on earth ${ }^{6}$. Soon Eurocurrency deposits and loans became an important money-market instrument to draw from. As domestic interest-rate ceilings kept domestic deposit rates often below surging inflation rates during the 1970s, US banks would encourage their corporate clients to deposit their funds in Eurodollars at market rates overnight. They would also borrow from their overseas subsidiaries, since Eurodollar loans were cheaper than domestic loans in the absence of regulatory costs.

As the Eurodollars thus gained money-market characteristics, they set the stage for other money-market instruments to emerge and thrive - negotiable certificates of deposits, excess bank reserves known as "federal funds," bankers'

(6) As rapidly growing US balance-of-payments deficits began to put pressure on the US dollar, US authorities tried during much of the 1960s and early 1970s to restrain capital outflows through such controls as voluntary bank-lending limits and a tax on American purchases of foreign stocks and bonds known as the Interest Equalization Tax. 
acceptances, commercial paper, and so on. All these new instruments got a huge boost from the introduction of money-market mutual funds in 1975 which soon became the most active buyers of such money-market instruments. These instruments enabled banks, and then later also increasingly non-bank financial institutions and even corporations, to fund themselves massively, if needed, at short notice. Having unrestricted access to money-market instruments made it easier for their users, notably banks and then hedge funds, to set much more aggressive assetgrowth targets and then cover any cash shortfall with stop-gap borrowings in the money markets.

When money-market funds took root in the late 1970s, they squeezed commercial banks greatly. Commercial banks suffered massive disintermediation out of their deposits which had been rendered less attractive because of regulatory interest-rate ceilings. Even after deregulation, bank deposits never fully recovered their once-dominant position. The Fed's flow-of-funds data (now called "financial accounts") show a steady decline of insured bank deposits from 52 percent of total short-term funding of the US finance sector in 1984 to just 31 percent in 2007 whereas the share of money-market fund assets rose from 5 percent to 21 percent. The national-income data of the US Commerce Department's Bureau of Economic Analysis (BEA) pertaining to the category of "traditional bank-based credit intermediation" shows that the commercial-banking activity of taking deposits and making loans actually declined from about 3.1 percent of GDP in 1985 to 2.4 percent in 2007. This apparent erosion of what we may best characterize as indirect finance (i.e. taking deposits, making loans) was part of a broader transformation in favor of a more direct finance arrangement involving markets and/or networks circulating tradeable securities.

\subsection{Securities replace loans as the primary channel of credit}

While funds replaced deposits as a principal form of saving, securities crowded out loans as a preferred form of credit. Financial intermediaries preferred securities over loans because of the kinds of income generation associated with each of them. Compared to the inherently volatile interest income associated with loans, the issue and/or trading of securities provides banks greater and more stable income sources in the form of fees, commissions, and trading profits. Sellers ("issuers") also have reason to prefer securities over loans. These allow them to tap a much broader supply of funds. Securities also come with lower costs than loans, in addition to being advantageous in terms of disclosure of information, requiring more formalized information in terms of income and balance-sheet statements whereas nosy bankers rely on relational information they can gather informally to assess their clients' creditworthiness. Finally, securities offer lenders (i.e. "buyers") liquidity and give them an exit option while loans are commitments hard to get out of. 
This shift towards securities has brought about an explosion of new financial markets since the 1980s beyond the already-discussed money markets. Notably, we are talking here about bonds, such as high-yield corporate bonds previously known as "junk bonds" or emerging-market bonds, derivatives, as well as loansecuritization products. The transaction volume of financial markets has also surged, with the Fed's financial accounts showing the value of traded equities and fixedincome securities in the United States to have grown from 107 percent of GDP in 1980 to 323 percent of GDP in 2007. This increase was also helped by steadily rising stock-market prices ${ }^{7}$.

This spectacular growth of market finance counter-acted the relative decline of indirect finance noted earlier. Capturing the "value added" component of finance included in our national income and product measures (i.e. profits plus compensation measured as net revenues minus non-wage inputs), the finance sector itself managed to expand from 4.9 percent of American GDP in 1980 to 8.3 percent in 2006. But we can also look at finance more broadly in terms of total output (or revenues), in which case the same national income data from America's Bureau of Economic Analysis shows this very sector to have grown from 9.5 percent of GDP in 1980 to 15.6 percent in 2007. This broader market-finance measure includes both traditional and alternative (i.e. hedge funds, private-equity funds, venture capital) asset management, pension-fund administration, derivatives trading and origination, equities and fixed-income trading, as well as broker-dealer services (including underwriting fees). This official measure of growth by the finance sector, however, excludes securitization, which took off from the turn of the century as a new growth engine for the finance sector.

Securitization involves the bundling of loans against which you write, passthrough securities whose income flows generated by the underlying loan pool (e.g. interest, repayment of principal) get passed onto their holders after deduction of origination and servicing fees going to the issuer. Ironically, it was the US government itself which encouraged securitization in the 1980s when governmentsponsored lenders Fannie Mae and Freddie Mac promoted mortgage-backed securities and the LDC debt crisis was resolved with the help of so-called Brady bonds facilitating a loan-for-bond swap. Securitization gained much more impetus when banks decided to move much of their lending activity off their balance sheets in the face of new capital requirements for bank loans under the Basel Accord of $1988^{8}$. Not only did this unloading of their loans allow them to avoid setting aside capital, but the banks could thereby also transfer credit risk to third parties. In

(7) See Federal Reserve (2014).

(8) Concluded among the Group of Ten countries under the auspices of the Bank for International Settlements and followed by over one-hundred countries, the Basel Accord asked banks to set aside more capital against their loans in proportion to the riskiness of such loans. 
addition, the banks got their money back much faster, enabling them to make a new loan rather than having to wait until the old loan was fully paid off. That acceleration of lending may not show up as such in the books of the banks where loans once unloaded were simply replaced by a new loan rather than aggregated. The aforementioned relative decline of indirect finance was hence more likely due to a greater share of it not being captured by official measurements. During the 2000s, securitization moved beyond mortgages into the money markets, when banks and their special-purpose entities used to run their off-balance-sheet operation began to bundle other types of household debt (e.g. student loans, car loans, and credit cards) against which they issued asset-backed commercial paper (ABCP) to borrow funds for the launch of their long-term capital-market securitization instruments.

Securitization helped drive up household debt, as the fraction of consumer debt held in securitized form rose from 8 percent in 1980 to about 50 percent in 2006. This increase in the household credit securitization share coincided with a rise in American household debt from 48 percent of GDP in 1980 to 103 percent in 2007. That massive increase was mostly fueled by securitization, given that the share of bank loans in total US consumer credit remained constant at around 40 percent of GDP throughout the period. Most of that securitization-driven increase in household debt involved mortgage debt, as this innovation made it easier and cheaper to finance home purchases. It thereby amplified existing incentive biases in favor of US home ownership (e.g. tax deductibility of mortgage interest) and so contributed to the overbuilding of America. This problem became acute during the housing bubble of the 2000s when two-thirds of all US homeowners turned their homes into cash registers by borrowing increasing amounts at an accelerating pace against their homes (through re-financings, second mortgages, home-equity loans) as home prices rose.

\subsection{The rise of shadow banking as network finance}

Securitization is part of the so-called "shadow banking system," which also comprises the aforementioned money-market funds and certainly also the specialpurpose entities which seek short-term funds in money markets (e.g. ABCP) in order to invest in longer-term instruments (e.g. mortgage-backed securities). Unlike banks, their credit intermediation occurs without access to the Fed's lender-of-last-resort facilities nor deposit insurance. Shadow-banking institutions also tend to organize their credit intermediation as a chain, with many more links than regular banking would have. Such lengthening of the intermediation chain has also been facilitated by another crucial pillar of the shadow-banking system, repurchasing agreements also known as "repos," a type of secured lending which rose from 5.9 percent of US domestic non-financial sector debt in 1980 to 15.5 percent in 2007. As an illustration of how repos facilitate making intermediation chains longer, banks often conduct reverse repos with hedge funds to fund the latter's purchases of asset-backed 
securities and then turn around to use thereby acquired securities to engage in their own repo financing where they typically borrow funds from money market funds (a practice known as "re-hypothecation"). The so-called "Credit Intermediation Index," a proxy measure for the lengthening of the intermediation chain by dividing total liabilities of all sectors with the total end-user liabilities (of households, nonfinancial firms, and government), rose from 1.83 in 1980 to 2.26 in $2007^{9}$.

Shadow banking is not part of so-called "market finance," but instead better characterized as network finance. Its structure consists primarily of a web of intertwined insider networks also known as "over-the-counter markets" which connect banks, broker-dealers, money market funds, hedge funds, and special purpose entities through securitization instruments, money-market claims, and repos. Even though normally existing off-balance-sheet and hence beyond official statistical measurements, the Financial Stability Board (2014) estimates shadowbanking to have grown to between $\$ 25$ and $\$ 35$ trillion in the United States. In terms of their output measure, shadow banks comprise somewhere between a quarter and thirty percent of the total finance sector. So, if we were to include them, shadow banks would easily push the output of the US finance sector from the official BEA figure of 15.6 percent to over 20 percent of GDP.

\subsection{Increased financial profit extraction}

The dramatic growth of market and network finance provided a rich source of income generation for the finance sector beyond its traditional intermediationbased income from indirect finance in the form of net-interest spreads - mostly in the form of fees, commissions, and trading profits. The BEA's national income data shows the proportion of total US corporate profits taken up by financial institutions to have risen spectacularly from 21.2 percent in 1979 to a 46 percent peak in 2002 before settling into a 38-41 percent range in the five-year period before the 2007 crisis amidst record high profits overall. Amidst that systemic crisis, the financial sector's profits collapsed to minus 10 percent of the total in the first quarter of 2009 , before bouncing back strongly to a 30 percent share by the end of 2010 .

This increased profit-extraction capacity of the financial sector, absorbing albeit in highly pro-cyclical fashion a growing share of the total corporate profit pie, may well have been underpinned by the rapidly rising market share of the largest US banks. In the wake of their deregulation and incredible advances in information and communication technology, these institutions managed to transform themselves during the 1990s and 2000s into universal banks with a global presence combining commercial banking, investment banking, fund management, and insurance under

(9) For a more detailed discussion on these data see also Robin Greenwood and David Scharfstein (2013). 
one roof for scale, scope, and network economies ${ }^{10}$. In 1990, the five largest US banks only controlled 9.7 percent of total assets in that sector. At the end of 2013 their combined market share had risen to an astounding 44 percent. In less than a quarter century US banking has gone from a highly decentralized, still predominantly regional industry to a supra-national and highly concentrated structure whose leaders have amassed one to two trillion dollars in assets each. This has left us with a serious "too-big-to-fail" problem we need to tackle.

\section{Financial growth dynamic}

\subsection{The "debt economy"}

One crucial aspect of financialization is that we have come to depend much more on debt financing of spending. Corporate debt rose in the United States from 31 percent of GDP in 1980 to 50 percent in 2007. More impressive, and indeed worrisome, was the doubling of the household-debt share over the same period to over 100 percent of GDP ${ }^{11}$. Most of that growth was the result of securitization, above all mortgages, while the expansion of corporate debt also came about through bonds rather than loans. This so-called debt economy has included the federal government as well. The US government's (net) debt level rose from 26.5 percent of GDP in 1980 to 68.7 percent in 2011. But this debt economy feeds on its own dynamic of instability. Hyman Minsky (1982, 1986, 1992), a leading PostKeynesians economist, explored the ties between debt, money, and economic activity in a very original approach. In particular he came to stress the importance of financial instability at the cyclical peak as a trigger of downturns. He also stressed that financial innovation, as exemplified by high-yield "junk" bonds for low-rated corporations and securitization products like mortgage-backed securities, have always played a crucial role in facilitating the level of indebtedness ("leverage") among private agents like firms or households. In Minsky's framework businesscycle dynamics are reinforced in both upswing and downswing phases by a parallel credit cycle whose turning point arises typically at the cyclical peak when acute explosions of financial instability of sufficient force push the economy into recessionary adjustment. For Minsky this is likely to happen when a growing number of debtors reach excessive levels of indebtedness during the upswing phase to render them highly vulnerable to any slowdown of income generation.

(10) Scale economies arise when greater production volumes ("size") yield efficiency gains driving down unit costs. Scope economies are synergies from combining different technologies or products which make one plus one equal more than two in product development. Network economies render those networks more valuable to their members with growing size.

(11) Robert Guttmann and Dominique Plihon (2010) have shown that the trend towards much-increased household debt levels has been evident in many industrial nations. 
Already early on in his career Minsky (1964) looked at the "debt economy" over several cycles to identify a long-wave dynamic a la Kondratieff whose financial dimension involved a supra-cyclical build-up of leverage and increased risk-taking over several business cycles during the upswing phase ${ }^{12}$. Once again, financial innovations are crucial in this process. But what Minsky was emphasizing here even more is the perverse impact of long periods of tranquility breeding instability. When things go well for a long time, people come to believe that this will continue to be the case indefinitely. Moreover, the occasional mild recessions during long boom phases (as during the 1950s and 1960s or from the early 1980s to the mid-2000s) are too short to make actors more risk-conscious in lasting fashion and too shallow to clear out any debt overhang or associated excesses. At the end of such a long-wave upswing, after a couple of decades of rapid growth and tranquility, both debt and the propensity for risk-taking will have reached dangerous levels. And this sets the stage for a major financial crisis, such as we experienced in the early 1970s or in the late 2000s.

\subsection{The "bubble economy"}

Minsky's identification of financial factors underlying long waves stressed not just the rise of debt relative to income over several cycles, but also the ongoing increase in the prices of key assets, notably stocks and real estate, to ultimately unsustainable levels. Our increased reliance on debt has been matched by the spectacular growth of financial assets on the other side of the balance-sheet ledger. Financial assets, summed across all sectors, have grown much more rapidly than national output from a FA/GDP ratio in the US of 4.8 in 1980 to a peak of 10.7 in 2007 before falling back to about 10 in 2010. During the same period, the ratio of financial assets to tangible assets rose from its long-term postwar trend level of 1.5 in 1980 to 3.5 in 2010. Tradable fixed-income assets ("bonds") grew mostly because of financial innovation, particularly loan securitization spawning new issues of assetbacked securities on a gigantic scale. Equity shares, on the other hand, grew because of rising stock-market valuations of firms and to a lesser extent also increased share volumes.

The debt-fueled expansion of financial assets on the books of private actors since the early 1980s coincided with the growing importance of capital gains possibly the most salient characteristic of the kind of finance-led capitalism we saw emerge during the early 1980s with the policy-enforced resolution of the global

(12) In the 1920s, the great Soviet economist Nikolai Kondratieff (1925/1984, 1926/1936) established, on the basis of longitudinal data of commodity price movements and credit aggregates, that capitalist economies seemed subject to 40-60-year cycles which he termed "long waves." Periods of sustained rapid growth lasting a couple of decades are followed by an equally long period of slow growth. 
stagflation crisis ${ }^{13}$. The chase for such trading profits (from the buying and re-selling of assets) benefitted from finance-led capitalism's propensity for sustained periods of asset inflation in the wake of speculative bubbles. During the upswing phase of the latest financial super-cycle from 1982 to 2007 the US economy experienced three consecutive asset bubbles, first the bull market fed by the corporate raiders' attacks on undervalued companies (1984-1987), followed by yet-another stock-market boom which came to be called the dot-com bubble in the wake of internet mania (1997-2000), to conclude with a huge and globally financed housing bubble (20022007). Such asset bubbles are not least a reflection of long periods of more or less uninterrupted economic expansion which create the necessary euphoric crowd psychology for explosive market rallies. When bubbles crash, accommodating monetary policy may set the stage for the next bubble. Asset bubbles typically feed off financial innovations which provide either new sources for debt-financing of asset purchases or create additional pathways to profit from sustained asset inflation.

The last bubble in the 2000s was special for several reasons. First, it did not focus on corporations and their shares, but instead took root among households pursuing the American Dream of home ownership. A series of financial innovations - new high-risk mortgage products, special-purpose entities at the heart of a new shadow-banking system, securitization extensions such as collateralized debt obligations or "structured finance" slicing asset-backed securities into tranches, or credit-default swaps and their use in "synthetic finance" arrangements - allowed banks to develop their new "originate-and-distribute" model which captured investors with the prospect of high yields at triple-A levels of quality and the ultimate borrowers with the notion of using one's home to draw cash from when its price rises. This was a far more broadly-based asset bubble than the previous ones, engulfing millions of Americans in boosting their spending power. What was crucial in this household-based bubble was the significant wealth effect that arose in its wake to boost consumer spending considerably during the bubble-fed boom. This wealth effect is both psychological, with households feeling wealthier due to rising asset prices (e.g. housing) even if the capital gains are not realized, as well as financial, to the extent that higher-valued assets boost owners' borrowing capacity by serving as loan collateral. As a result, the personal savings rate declined to the extent that capital gains replaced the need to put some money aside for later use. BEA data show that the US personal savings rate, as a percentage of after-tax disposable income, fell from 10.9 percent in early 1982 to minus 1.8 percent just before the crisis hit in mid2007. In another indication of bubble-driven excess spending, the US trade deficits moved during the same period from minus 0.8 percent of GDP to minus 6.1 percent

(13) Some heterodox economists, such as Eckhard Hein (2012) or Robert Guttmann (2016), have tried to push their conceptual framework in their analyses of contemporary capitalism beyond the notion of "financialization" to denote the entire system as "finance-dominated" or "finance-led." 
of GDP. The richest country in the world thus ended up with a negative savings rate and in addition turned from the world's leading capital exporter into the largest net debtor within less than a quarter of a century.

\section{The systemic crisis of finance-led capitalism}

It should not come as a surprise that FLC's propensity for a "bubble economy" has been most pronounced in the United States. Americans have cultural biases which set them up for such speculative excesses more than other cultures, notably a get-rich-quick mentality and a positive attitude toward debt. But there are also institutional factors to consider. Most important among those is the dollar-based international monetary system and the privileged position occupied by the United States in that system. Having to supply other countries with dollars for their crossborder payments, the United States needs to run chronic balance-of-payments deficits with which to sustain steady outflows of dollars to the rest of the world. Those external US deficits are automatically financed by anyone outside the United States using dollars as an international medium of exchange or store of value. Thus, being the only country on the planet not having to face any external constraint, the United States can as a result run much more stimulative economic policies than anyone else without having to worry about its external position, the level of its foreign-exchange reserves, or exchange rates - a huge advantage which I have termed elsewhere "global seigniorage" (Guttmann, 1994; chap. 15)14. This advantage extends to having much of the world's financial assets and liabilities denominated in US dollars, an asymmetry that helps the United States more easily maintain the deepest and most liquid financial markets.

This privileged position has led the United States to play the role of "locomotive" for the world economy. During the Bretton Woods phase (1945-1971), the US acted as global stimulator via overvaluation of its currency and capital exports that helped fuel the catching-up process of other industrial nations (Germany, Japan, etc.) around export-led growth strategies. Dramatic shifts in US policy mix breaking the global stagflation dynamic (1979-82) saw the US economy alter its locomotive role by becoming the world's "consumer of the last resort." After 1985, the US ran up growing trade deficits, which were financed by the rising trade surpluses of the rest of the world being recycled as capital exports to the US. With a trade deficit equaling $7 \%$ of its GDP just before the crisis hit in 2007, the US ended up absorbing almost half of the world's savings while running a negative savings rate of its own.

America's latest asset bubble assumed in this context a special role in the growth dynamic of the world economy. Financial innovations related to home ownership, notably mortgage re-financings and home-equity loans, allowed US

(14) See Stephan Schulmeister (2000) for further elaboration of this global-seigniorage concept. 
households (69\% of whom are home-owners) to cash in capital gains from rising housing prices without having to sell off their homes. US banks launched their own mortgage-backed securities in the late 1990s and then, after 2003, found a way to repackage pools of riskier non-traditional mortgages into high-grade securities (by transforming mortgage-backed securities into collateralized debt obligations. The influx of funds generated by these securitization techniques financed a historic realestate boom which fueled excess consumption in the US and export-led growth elsewhere. As Americans consumed the equivalent of 107 dollars for every 100 dollars they produced as income, their bubble-driven and debt-financed excess consumption absorbed the rest of the world's expansion via foreign trade. This absorption not only helped sustain the rapid growth of China and other emergingmarket economies (many of whom, like Brazil, benefited in addition from a supracyclical boom in commodities triggered by China's breakneck expansion at doubledigit growth rates), but also enabled the European Union and the East Asian tigers as well as Japan to recover from their respective crises of the 1990s. The entire world community (minus America) came to depend on export-led growth amidst declining wage shares at home!

When the subprime crisis broke America's housing bubble in 2007/08 and then plunged the entire world economy into a steep decline during 2009, it was only the extraordinary policy response of the world's leading economies which prevented this crisis from becoming another depression akin to the one we experienced in the 1930s. Coordinated by the newly upgraded G-20 global governance structure, the United States, Canada, the European Union, Japan, China, and key emerging-market economies such as Brazil used a combination of massive bank bailouts, unorthodox monetary policy ("quantitative easing"), fiscal stimulus packages, and explicit commitment to maintain open borders to turn around the debt-deflation spiral that was triggered when the bankruptcy of Lehman Brothers suddenly paralyzed the world's money markets in September $2008^{15}$.

Still, while the worst was thus avoided, the crisis has left us facing long-term stagnation as is typical for the slow-growth downswing phases of long waves (see also the period from 1873 to 1896 or 1971 to 1982). For one, the crisis has stopped bubble-fueled growth and thus exposed massive overproduction conditions in a large variety of manufacturing and trade-dependent service sectors across the globe. These had been covered up for quite some time by consecutive US bubbles turning Americans into consumers of last resort absorbing the current-account surpluses of the rest of the world. Once Americans ceased to play this role amidst collapsing housing prices and excessive consumer debt levels, the rest of the world was

(15) Major systemic financial crises at the end of long-wave upswings typically trigger widespread deleveraging efforts by over-indebted debtors and forced distress sales of their assets into declining markets. This financial-crisis dynamic sets off what Irving Fischer (1933) had famously characterized as a "debt-deflation spiral." 
deprived of their excess demand on which so many countries had come to depend. Furthermore, the post-crisis stagnation dynamic has also been fed by a new type of monetary protectionism. When the Fed launched its quantitative-easing program in 2009, it thereby drove down the US-dollar against the euro. That exchange-rate effect of excessive easing helped amplify the subprime crisis' asymmetric shock to the euro-zone and plunged its members into a systemic crisis (between October 2009 and May 2012). Once the European Central Bank adopted its own quantitativeeasing program during 2012 it thereby drove down the euro which put added pressure on Japan and China. The latter's slowdown collapsed the commodities' super-cycle to hurt commodity producers like Russia or Brazil. Finally, the world's financial institutions and markets have been severely hurt by the systemic crisis of 2007/08. Key banks still carry large losses on their books and also find themselves squeezed by the spread of negative interest rates across the globe - an absolutely path-breaking new development whose implications we have yet to fully appreciate. Add to this the rather substantial re-regulation effort pertaining to banks, in particular America's Dodd-Frank Act of 2010 (most provisions of which have also been adopted in the United Kingdom and the European Union) and the global Basel III accord of 2010. The new regulatory restrictions are designed to slow down banks and force them to downsize considerably, hence they are no longer fueling credit-financed expansion or asset bubbles ${ }^{16}$.

There is one obvious way to overcome this long-term stagnation worldwide, and that is to launch a massive re-industrialization effort in the face of climate change. This environmental catastrophe can be avoided if we change our energy mix from fossil fuels to renewables, retro-fit our cities, revolutionize our transport systems, retool our industries, and transform agriculture. The Paris Climate Accord of 2015 may be the opening shot for such a profound transformation of our economic structure, as it commits all the countries of the world to cut greenhouse gas emissions substantially over the next couple of decades. Such a huge effort must be combined with other reforms centered on the public goods of sustainable development and social justice which will oblige us to find another, less destabilizing dynamic of globalization. History does show that capitalism can be reformed to get out of crisis, as evidenced by Roosevelt's New Deal reforms of the 1930s or the Bretton Woods agreement of 1944. But this task requires of us, economists, a better understanding of the historic, social, and institutional dimensions of capitalism than our obsession with mathematical (and hence a-historic, non-social) modeling can provide! More than ever there is a historical imperative for heterodox economists to do their job!

(16) Several influential US economists have put forth their own explanations for the slow-growth scenario which has taken root globally since the crisis of 2007/08, notably the "secular stagnation" argument of Lawrence Summers (2016) and the "productivity slowdown" argument of Robert Gordon (2016). 


\section{Bibliography}

CIPRIANI, M.; MARTIN, A.; PARIGI, B. Money markets funds intermediation and bank instability. Federal Reserve Bank of New York Staff Reports, n. 599, Feb. 2013. Disponível em: https://www.newyorkfed.org/medialibrary/media/research/staff reports/sr599.pdf.

EPSTEIN, G. Financialization and the world economy. Cheltenham, UK: E. Elgar, 2005.

FEDERAL RESERVE. Financial accounts of the United States: flow of funds, balance sheets, and integrated macroeconomic accounts. Washington, DC: Federal Reserve Board of Governors, 2014. Disponível em: http://www.federalreserve.gov/releases/z1/current/z1.pdf.

FISHER, I. The debt-deflation theory of great depressions. Econometrica, v. 1, n. 4 , p. 337-357, 1933.

FINANCIAL STABILITY BOARD. Global shadow banking monitoring report 2014. Basel, CH: Financial Stability Board, 2014. Disponível em: http://www.fsb.org/2014/11/fsb-publishes-its-fourth-global-shadow-bankingmonitoring-report-2014/.

GORDON, R. The rise and fall of American Growth. Princeton, NJ: Princeton University Press, 2016.

GREENWOOD, R.; SCHARFSTEIN, D. The growth of finance. Journal of Economic Perspectives, v. 27, n. 2, p. 3-28, 2013.

GUTTMANN, R. How credit-money shapes the economy: the United States in a global system. Armonk, NY: M. E. Sharpe, 1994.

GUTTMANN, R. Finance-led capitalism: shadow banking, re-regulation, and the future of global markets. New York: Palgrave Macmillan, 2016.

GUTTMANN, R.; PLIHON, D. Consumer debt and financial fragility. International Review of Applied Economics, v. 24, n. 3, p. 369-383, 2010.

HEIN, E. The macroeconomics of finance-dominated capitalism - and its crisis. Cheltenham, UK: Edward Elgar, 2012.

HEIN, E.; VAN TREECK, T. 'Financialisation' in post-Keynesian models of distribution and growth. IMK Working Paper, Düsseldorf, Germany, n. 10, 2008.

INTERNATIONAL MONETARY FUND. Foreign Direct Investment trends and statistics. 2003. Disponível em: http://www.imf.org/external/np/sta/fdi/eng/2003/ 102803.htm. 
KONDRATIEV, N. (1925). The major economic cycles (in Russian). Moscow. Translated as The long wave cycle. New York: Richardson \& Snyder, 1984.

KONDRATIEV, N. (1926). Die langen Wellen der Konjunktur. Archiv für Sozialwissenschaft und Sozialpolitik, v. 56, p. 573-609. Published in english as The long waves in economic life. Review of Economic Statistics, v. 17, n. 6, p. 105-115, 1936.

KRIPPNER, G. The financialization of the American economy. Socio-Economic Review, v. 3, n. 2, p. 173-208, 2005.

KRIPPNER, G. Capitalizing on crisis: the political origins of the rise of finance. Cambridge, UK: Harvard University Press, 2012.

MINSKY, H. Longer waves in financial relations: financial factors in the more severe depressions. American Economic Review, v. 54, n. 3, p. 324-335, 1964.

MINSKY, H. Can 'it' happen again? Essays on instability and finance. Armonk, NY: M. E. Sharpe, 1982.

MINSKY, H. Stabilizing an unstable economy. New Haven, CT: Yale University Press, 1986.

MINSKY, H. The financial instability hypothesis. Annandale-on-Hudson, New York: Levy Economics Institute, May 1992. (Working Paper, n. 74). Disponível em: www.levyinstitute.org/pubs/wp74.pdf.

PALLEY, T. Financialization: what it is and why it matters. Annandale-onHudson, New York: Levy Institute, 2007. (Working Paper, n. 525). Disponível em: http://www.levyinstitute.org/pubs/wp 525.pdf.

SCHULMEISTER, S. Globalization without global money: the double role of the dollar as national currency and world currency, Journal of Post Keynesian Economics, v. 22. n. 3, p. 365-395, 2000.

SUMMERS, L. The age of secular stagnation: what it is and what to do about it. Foreign Affairs, v. 95, n. 2, Mar./Apr. 2016. Disponível em: https://www.foreignaffairs.com/articles/united-states/2016-02-15/age-secularstagnation.

UNCTAD. Global Investment Trends Monitor, n. 11, Jan. 2013. Disponível em: http://unctad.org/en/PublicationsLibrary/webdiaeia2013d1_en.pdf. 